Article

\title{
People, Governance and Forests-The Stumbling Blocks in Forest Governance Reform in Latin America
}

\author{
Arnoldo Contreras-Hermosilla \\ Forest Policy Consultant based in Italy, Via Vittorio Emanuele 21, Labro, 02010 Rieti, Italy; \\ E-Mail: arnoldocontreras@ comcast.net; Tel.: +39-335-8447498
}

Received: 02 November 2010 / Accepted: 23 December 2010 / Published: 27 January 2011

\begin{abstract}
This article examines common barriers to achieving adequate levels of forest resource governance in countries of Latin America. It looks at the deficiencies of the policy and regulatory frameworks affecting forests, the common failure to impose the rule of law, the main factors that constrain the effectiveness of government actions in the forest sector and at the political barriers to introducing reforms for change in governance structures. The elimination of these barriers acquires new importance in the implementation of successful REDD+ programs in the countries of the region.
\end{abstract}

Keywords: forest governance; governance reform; REDD+ programme; Latin America

\section{Introduction}

For years, governments in Latin American have tried to reduce deforestation, forest degradation, and improve the management of forest resources generally, but with disappointing results. Faulty policy and legislative frameworks, weak rule of law, illegal logging, corruption, ineffectual forest institutions and various other governance failures have plagued forest management.

The implementation of Reduced Emissions from Deforestation and Forest Degradation and improved resource management (REDD+) provides a new and unprecedented opportunity for reforming governance systems in the region. REDD+ schemes are likely to become sizeable funding sources for initiatives to reduce deforestation and manage forests in sustainable ways. However, beyond potentially considerable financing, the implementation of REDD+ schemes will require countries to organize exceptional efforts to improve the quality of forest governance [1]. Without an acceptable level of forest governance, REDD+ initiatives could fail to reduce emissions, and worse still, 
could lead to a wide array of perverse results. Large flows of funds under REDD+ programs could lead to increased conflict, considerable opportunities for corruption and negation of the rights of indigenous peoples and forest-dependent communities. Improving forest governance is therefore a critical task.

This study reviews some of the most important barriers to achieving adequate forest governance in Latin American countries. The next section looks at key challenges to improving the quality of forest governance common to most Latin American countries. The four sections after that examine each one of the main obstacles to governance in greater detail. Section 3 looks at the common failures of the policy and regulatory frameworks affecting forests. Section 4 examines barriers to governance related to the weak rule of law and its manifestation in the frequency of illegal logging. Section 5 examines deficiencies in government effectiveness and Section 6 focuses on the rigidities and political resistance that make attempts to introduce policy, regulatory and institutional reforms to improve governance a difficult undertaking. Section 7 presents some concluding remarks.

\section{Challenges to Improving the Quality of Forest Governance}

Forest governance is a broad term than can sometimes be used to mean different concepts. Here, forest governance is understood as the ways in which officials and institutions (both formal and informal) acquire and exercise authority in managing the resources to sustain and improve their economic productivity, environmental values and the welfare and quality of life for those whose livelihoods depend on the sector. This governance concept is thus multidimensional in its values, multi-actor from the private and public sectors and involves different levels of government, from international to national and local. While all-encompassing conceptual frameworks are useful in obtaining a detailed understanding of forest governance, this paper will focus on those issues where the government is seen as the principal agent to initiate action and reforms. These include the design and application of policy and regulatory frameworks, and action by government institutions to implement regulations affecting forests in community, private and public ownership or control. We examine obstacles to forest governance and their relevance to the implementation of forest carbon programs in the following key dimensions:

- The policy and regulatory framework affecting forests. This refers to the ability of government to design, formulate and implement sound policies and regulations that permit and promote sustained forest management.

- Respect for the rule of law, control of illegal forest activities and corruption. This is the extent to which agents have confidence in and abide by the society's rules and, in particular, the quality of contract enforcement, property rights, the police and the courts, as well as the likelihood of crime and violence. It includes the extent to which public power is exercised for private gain, including both petty and grand forms of corruption, as well as "capture" of the state by elites and private interests.

- Government effectiveness. This refers to the quality of the bureaucracy and the public services provided, the degree of the bureaucracy's independence from political pressures, and the credibility of the government's commitment to its own policies. 
- The political economy of introducing reforms. This relates to the ways in which reforms are planned and effectively implemented. It relates to the flexibility of government to deal with diverse interest groups and overcome resistance to policy and regulatory reform.

It is important to note that while these dimensions of forest governance appear to be independent areas of study, they are in fact closely interrelated. A degree of correlation can therefore be expected between, for example, high levels of corruption and low government effectiveness, or between a dysfunctional policy and legal framework on the one hand, and weak rule of law on the other. The implication is that while overcoming one or a few barriers may certainly help, this may not be necessarily sufficient to achieve higher overall forest governance levels.

These forest governance dimensions acquire new relevance in the implementation of REDD+ programs in Latin American countries, as the programs require considerably enhanced levels of governance effectiveness and efficiency.

\section{Failures of the Policy and Regulatory Frameworks}

A review of the regulatory environment quite often reveals flaws in government policy and regulatory frameworks to direct the management of public and privately owned forest resources; these flaws commonly result in undesirable effects, sometimes leading forest actors in directions that are sharply at odds with the original intentions of policy makers and legislators.

Governance failures originate not only in flawed forest policies and laws, but also in policies and laws in other sectors. For instance, policies and regulations on agricultural expansion, land tenure, industrial and transportation infrastructure development can all have a profound negative impact on forests [2].

We examine eight characteristic weaknesses of policies within and outside the forest sector that introduce important barriers to governance of forest resources and the adequate management of REDD+ programs.

\subsection{Regulatory Overburden}

Regulation in the forest sector is normally very intense and detailed. Norms control how forest resources should be managed, when and what forest products can be harvested in what locations and how forest products should be transported and traded. In comparison, other land users such as agricultural operators are not subject to such profuse, regularly excessive, regulation.

Box 1 displays the degree of overall economy-wide regulatory burden of Latin America. No such index is available for the forest sector as such, but there is no compelling reason to think that the situation in the forest sector would be radically different from that of the economy as a whole. The score for each country is a number between 0 and 100, with 100 equaling the most liberal business environment. The score is based on 10 factors, all weighted equally: Starting a business: (a) procedures (number), (b) time (days), (c) cost (per cent of income per capita), (d) minimum capital (percentage of income per capita; Obtaining a License: (a) procedures (number), (b) time (days), (c) cost (percentage of income per capita); Closing a business: (a) time (years), (b) cost (percentage of state), (c) recovery rate (cents to the dollar). There are sharp differences between countries, with some showing considerable regulatory burdens. In 
Suriname, for example, starting a business requires 13 administrative procedures and takes 694 days at a cost equal to $113 \%$ of the nation's per capita income. Enforcing contracts on average takes 44 administrative procedures, 4.7 years and consumes as much as $37 \%$ of the claim [4]. In contrast, in Colombia, starting a business requires nine administrative procedures that can be completed in 20 days and costs $12.8 \%$ of the country's per capita income [5].

Box 1. Business Freedom Index in selected countries of Latin America, 2010 [3].

\begin{tabular}{cc}
\hline Country & Score \\
\hline Argentina & 62.1 \\
Belize & 74.1 \\
Bolivia & 57.3 \\
Brazil & 54.5 \\
Chile & 64.8 \\
Colombia & 83.6 \\
Costa Rica & 59.3 \\
Ecuador & 52.9 \\
El Salvador & 67.4 \\
Guatemala & 52.5 \\
Guyana & 63.4 \\
Haiti & 36 \\
Honduras & 63 \\
Mexico & 83 \\
Nicaragua & 55.7 \\
Panama & 75.9 \\
Paraguay & 60.9 \\
Peru & 65.8 \\
Suriname & 41 \\
Uruguay & 63.1 \\
Venezuela & 50.3 \\
\hline
\end{tabular}

Generally, excessive regulation is not associated with better economic or environmental outcomes but instead is often associated with considerably higher degrees of corruption and a greater relative size of the unofficial economy $[3,6]$.

When use of land for forests are subjected to excessive regulation, while other land uses are not, an incentive is created to abandon forests and dedicate land to the more lightly regulated non-forest alternatives. While the regulatory environment is variable in the region, in some cases regulatory overburden may be an important cause of deforestation. For example, excessive regulation is considered one of the main causes of deforestation and forest land use conversion in Colombia [7].

The relevance of this barrier to REDD+ programs is clear, as these programs aim to reduce or eliminate inducements to deforestation and forest degradation.

\subsection{Unrealistic Regulations}

Apart from excessive forest regulations, a frequent problem is that some regulations are so demanding that many forest operators cannot possibly satisfy them. 
For example, while the Honduras government requires communities to prepare forest management plans before using the forest in any way, most communities simply do not have the technical capacity to design and implement the required plans or, unless they receive support from assistance projects, the capability to hire a forest professional who can produce such plans In those cases where plans could somehow be designed, it would take two years to obtain government approval [8]. In Paragominas, in the eastern Brazilian Amazon, the local forest service was not authorized to approve forest management plans and small scale loggers had to travel to the state capital of Belem to obtain government approval. It could take several days, and frequently several trips, to complete missing or erroneous documentation required by the government [9]. This was well beyond the capacity of many small operators.

In Bolivia, a government interested in regularizing conditions for local communities encouraged them to form Local Community Groups, which could then apply for permission to use municipal forests. However, the start-up costs could be as high as US\$20,000 with annual recurrent costs up to $\$ 8,000$. Most local communities lacked the resources and technical capacity to satisfy government requirements and therefore could not access the program benefits [10].

Analogous cases of unfeasible regulation exist in other countries. Because they have meager technical and financial resources, small operators are at a disadvantage compared with large producers and corporations. These latter entities may also know better how to navigate the complex web of laws and regulations and enjoy better contacts in government agencies who can help to move official papers and authorizations along.

As in the case of excessive regulations discussed above, forest owners facing perhaps fewer but unaffordable and still unfeasible rules have an incentive to convert their forests to other uses that require less demanding compliance with government rules. In other circumstances, they may simply choose to operate outside the law. REDD+ programs will be hampered by the inability of some stakeholders, particularly small operators and communities, to comply with regulations that are well beyond their capacity. Some observers have already pointed out that communities and small forest landowners will need substantial help to comply with the requirements for REDD+ implementation.

\subsection{Policies that Ignore Rights to Forest Use and Ownership}

In various Latin American countries, the lack of land rights recognition creates significant barriers to proper forest governance. Traditional rights are, for all practical purposes, legally non-existent even though these populations may have been the original occupants and used the forests for their subsistence since time immemorial. Apart from the unfairness of these policies, the lack of secure and legal forest land tenure leads to intense conflicts between communities and governments. Conflicts about forest resources ownership and rights complicate decisions about forest management. In Suriname, tribal land rights are still not legally sanctioned by the government, which grants licenses to non-tribal people and companies, thus leading to intense friction between traditional communities, government and licensees. In other parts of the region, these policies have been the source of violent uprisings and local conflicts between rural communities, government agencies and corporations that attempt to impose their control over traditional forest lands under various timber concessions and other government-sanctioned forest utilization schemes [11,12]. 
While it is recognized that in many countries governments are reforming land tenure policies in favor of indigenous communities' ownership (Box 2), often the gap between formal legal rights and the reality is still wide [14]. Further, rights frequently come with limits. In Guyana, for example, Amerindians' rights have been regulated in the Amerindians Act of 2006 but significant restrictions on land use persist.

Box 2. Indigenous community forest ownership.

During the past two decades, some countries have granted legal ownership of forests to indigenous communities: Bolivia, 12 million ha; Brazil, 103 million ha; Colombia, 27 million ha; Ecuador, 4.5 million ha; and Guyana, 1.4 million ha of land, including forests.

Source: [13]

An assessment of the lessons learned in implementing the initial steps of REDD+ country initiatives reveals that about half the countries analyzed faced serious issues related to land tenure and uncertainty affecting user rights, making this a key barrier to the effective implementation of forest carbon programs [15]. The assessment involved diverse uses of forest resources and lands in different situations, from programs on government lands (Guatemala), to others on community-owned lands (Mexico), on indigenous peoples' territories (Brazil) and on private lands (Ecuador).

Unclear land tenure also has economic and environmental repercussions. Land not legally owned cannot be used as collateral for obtaining loans or for any kind of secure and enforceable transaction. Similarly, uncertain land tenure deters long-term sustainable management and in fact makes deforestation a more attractive option.

\subsection{Unclear and Contradictory Policies and Regulations}

Several regulations may have a direct impact on forest governance, but they may not always be harmonized or consistent with each other. The possibilities for conflicting regulations multiply if laws and norms are numerous. Mexico, for example, has more than 100 laws for environmental regulation, with discrepancies and conflicts among them [16].

Further, it is common for governments to pass laws but delay or never issue the corresponding operational regulations. For example, the Forest Management Act of Suriname was approved in 1992, but the implementing regulations were issued only eight years later, creating great uncertainty about how the law should be put into practice in the meantime [12].

In other situations, operational regulations may be unclear and thus open to conflicting interpretations (Box 3). Again, these limitations create strong incentives for operators to move away from forest-based management and to convert lands to uses with fewer regulatory complications. 
Box 3. Unclear rules in Guyana.

'Some requirements pertaining or related to the New Forest Act were being implemented before its recent approval in 2009 despite doubts about their legal validity. The Code of Practice for Timber Harvesting (GFC November 2002) was a typical case. The Forest Act established a procedure for the approval and coming into force of codes of practice. Defined as "a voluntary guideline," effective in regulating all stakeholders in meeting SFM international best practices, the Code of Practice was considered as legally binding by Guyana Forestry Commission (GFC) authorities. The latter regarded its enforcement as "implementation of procedures", "acting in keeping with the mandate of the GFC." They claimed concessionaires had to follow official guidelines as a matter of principle, and that this was stated in their permits. Explicit references to the Code were included in new permits and renewals.

Forest users did not totally share this view. One extensive complaint among managers of forest companies was the alleged "no legal basis" for many GFC requirements and guidelines. On the other side of the producer spectrum, chainsaw millers and small loggers insistently considered them as "impromptu rules" and "new rules" by GFC. Some private sector managers also questioned the legality of the GFC enforcing "compensations" above G\$750 (some US\$4), a limit stated in the Forest Act. (The GFC applied compensations on the basis of the estimated market value of the involved produce.) Those company managers questioned a whole array of procedures. This situation persisted for some years. It created unnecessary conflict fueled by uncertainty on rules and obligations".

Source: [17]

\subsection{Weak Social and Environmental Safeguards Related to Developments in Other Sectors}

It is well known that transportation infrastructure, as well as mining and oil extraction operations, create strong incentives for opening up new forest areas previously protected from loggers and other operators by their inaccessibility. Building roads near or through forests leads to increased opportunities for illegal and environmentally damaging logging, deforestation and forest degradation. New roads increase accessibility and the financial profitability of converting forested lands to agriculture. As the price of newly "developed" lands grows, the first occupants tend to sell their now more valuable land holdings and move further into the forests [18]. Roads cutting through forest areas are a significant cause of deforestation in Brazil, where each kilometer of new roads leads to between 400 and 2,000 ha of deforestation. There is also abundant evidence of the deleterious effects of road construction policies in Peru, Ecuador and Mexico [16,19-21]. A study of roads projects in Mexico, Guatemala and Belize estimated that their construction would cause the deforestation of some 300,000 ha [22].

Although road projects are increasingly planned with deforestation safeguards, protective measures are not always respected. As one observer points out, in the countries that share the Amazon basin, "after 60 years of building some tens of thousands of kilometres of roads, there is no single example of planning and legislation being minimally applied" [23]. This includes the enormous 4,700 km road between Lima and Brasilia.

Mining, oil and gas projects also have damaging impacts by causing deforestation in extraction sites as well as pollution. Erosion, siltation and contamination may be exacerbated by spills, tailings dams and the release of chemicals used in extractive procedures, all of which can have powerful negative impacts on forest resources, the environment and local people [17,19,24]. For example, illegal gold 
mining in the Brazilian Amazon and more recently across the border in Venezuela has caused extensive deforestation despite government efforts to stop these destructive practices.

In addition to direct deforestation, many mining and oil and gas extraction ventures may cause intense conflict with local communities. A dramatic situation is in the Peruvian Amazon, where oil and gas blocks alone already cover some 55 million ha (See Box 4). As much as 45 million ha under oil and gas exploration contracts overlap with lands claimed by indigenous groups [24,25]. After new regulations governing the use of forest resources were issued, 100 people died in clashes with military police in 2009 during violent protests by indigenous groups denouncing a lack of consultation and violation of their ancestral land rights overlapping with oil and mining exploitation projects [25,26]. Similar situations in Venezuela, Ecuador, Guyana and other countries have also led to violent conflicts between indigenous groups, government institutions and oil, mining and gas exploration companies.

Box 4. The Peruvian Amazon: infrastructure, mining/oil works and other development projects.

52 active hydroelectric projects in the Amazon will generate some 24,500 MW, but flooding forests behind the dams is likely to cause negative environmental impacts, including large greenhouse gas emissions.

- 53 oil blocks in the Amazon will cover some 55 million ha. Some 35 million ha have already been allocated. The exploration process alone has resulted in some 16,000 ha being deforested.

- 24,818 mining concessions, only 16 of which are legal. In Madre de Dios, some 150,000 ha are already seriously affected by mining.

- 483,000 hectares of new biofuel plantations. Replacing natural forests with oil palm plantations for ethanol production results in 50\% more greenhouse gas emissions than petroleum.

Source: [23]

Trevin and Nasi [17], discussing the Guyana case, state:

The forest resources of Guyana are still largely healthy and productive. Some threats are already visible, though, and they may be expected to increase, unless properly managed ... Mining is one of these threats. Many forest users perceive mining as functioning without any rules. They resent what appear to be significant differences in control with their activity. Small loggers would say "miners enter the concession and do whatever they want, and the concessionaire is charged". A community forestry association representative ironically suggested, "We should all shift to mining and then ask permission to sell the trees." Mining is described as a "big problem" by forest company managers. "Some TSA (Timber Sales Agreements, issued by government for concessions covering more than 24,000 ha and allocated for more than 20 years) covered in $90 \%$ by mining rights." Mining has also been recognised as an obstacle for forest certification.

The negative impact of oil extraction in the Ecuadorian Amazon has been well documented in a protracted lawsuit filed in the US on behalf of 30,000 forest dwellers against an oil company that causes massive damage to forests and water supplies. Amazon Watch estimates that about one million hectares of forest have already been degraded. 
Thus, the development of extractive industries tends to promote deforestation and forest degradation through the extractive operation itself and greater accessibility to forest areas. In addition, the imposition of extractive rights above those of traditional communities risks generating intense conflict between extractive industries, governments that sanction these developments and local communities. The high value of mineral, oil and gas resources make the opening forests for extractive operations and new roads generally unavoidable.

In terms of REDD+ implementation, the high levels of uncertainty tend to discourage various actors in forest investments to engage in preventing deforestation. Further, these situations are bound to make it difficult to identify those responsible for reducing deforestation and reward them accordingly.

\subsection{Fiscal Policies that Encourage Unsustainable Uses of Forests}

Various fiscal policies result in substantial financial resources from taxpayers, in the form of subsidies, being transferred to a limited number of consumers and producers. Globally, government subsidy policies in the forestry sector are substantial, reaching some $\$ 30$ billion a year [27]. However, subsidies provided with the best of intentions often fail to produce the expected results, and when they do, the results are often achieved at a high cost. In extreme cases, forest subsidies induce responses opposite to those sought by policy makers, a remarkable example of governance failure.

Large areas of forest resources in the region are managed under various timber concession contract schemes. Traditionally, fees charged and other conditions governing contracts with concessionaires have little relationship to the actual value of forest resources. It is not unusual to see governments capturing only a tiny fraction of the forest economic rent (the financial return from harvesting trees above that earned elsewhere in the economy). Governments can capture part or all of the value of forest resources. It is not unusual to see governments capturing only a tiny fraction of the forest economic rent through a wide variety of forest charges. If they choose not to do so, extraordinary profits accrue to concessionaires as subsidies and exceptional profits. In many cases, charging low timber fees is done intentionally as a subsidy, to attract forest companies, create employment and open previously inaccessible lands to development. In some other cases, unrealistically low fees are not intentional but the result of inflation with governments neglecting to include clauses in their timber concession contracts for periodic revision and adjustment of the real value of forest fees. Thus, one way or another, timber concessionaires may be subsidized, when they pay timber or other forest fees that are well below the true market value of products they extract from public forests.

Low forest fees create incentives to follow unsustainable management practices and tend to have negative impacts on local people. For example, cheap wood tends to be wasted by timber concessionaires. Because wood from concessions is inexpensive, potential concessionaires naturally tend to obtain as large a concession as possible. In either case, large areas under concession increase the likelihood that concessionaries will obtain control of traditional lands used by local communities and indigenous groups, thus multiplying the opportunities for conflict.

Some countries have also established subsidies for forest plantations with the commendable intention of reducing pressure from industry on natural forests (Chile is one such case). Plantation forests can produce far more industrial wood per hectare than natural forests and therefore if plantation wood and natural forest wood were perfect substitutes (which they are not), subsidies would contribute 
to reducing demand for natural forest products. However, the changes in market prices that accompany subsidies may lead to substantial misallocation of resources and economic inefficiency. If plantation wood is in fact successful in replacing timber from natural forests, the value of natural forests may decline substantially due to reduced demand for their products and this, depending on the pressures on land, may induce natural forest clearing to use the lands for more profitable alternatives, including planted forests [27].

In other instances, governments subsidize agriculture, and by doing so they shift the margin of financial profitability for activities that may compete with forest uses of land. Due to distorting subsidies, private agriculture may expand beyond economically sensible limits and encroach into forest lands. This conversion effect may be particularly intense when land is scarce. Depending on the circumstances, agricultural subsidies may lead to agricultural intensification rather than higher pressure on land, but often the expansion of agricultural crops into forest lands is a more profitable option. For example, in Mexico, subsidies to provide incentives to develop biofuels have led to forest clearing to plant oil palm [9]. In addition, agricultural intensification tends to be capital intensive, frequently reducing local demand for labor. In some cases, displaced workers have moved into forested areas in search of livelihood opportunities, thus increasing pressures for deforestation and forest degradation $[28,29]$.

These examples show that subsidy policies in the forest sector frequently produce a host of undesirable effects, sometimes quite at odds with the original intentions of policy makers. Also, agricultural subsidy policies that favor land uses that are different from forests, may easily lead to increased deforestation and the expansion of the agricultural frontier. These incentives to deforestation are likely to be a key issue for implementing REDD+ programs, which rely on increasing financial rewards for alternatives that keep lands under forests. It is questionable whether these rewards will always be sufficient to overcome the financial profitability differential accruing to those who opt for deforestation and conversion of forest lands to more financially attractive agricultural alternatives.

\subsection{Policies that Directly Promote Deforestation and Forest Degradation}

In Brazil, historically, deforestation was accepted as a way to improve land, giving access to property rights. The 1964 Land Statute supported this concept and in 1980 squatters were granted the right to claim and possess land which they kept in production for five years [14].

In Mexico, the government recognized possession of lands where communities could demonstrate their "productive use", such as agriculture or cattle ranching. In contrast, the government did not provide titles for forested lands. Thus, this policy directly introduced a powerful incentive for forest conversion, particularly to cattle ranching, in order to secure land titles. The area dedicated to cattle ranching expanded from some 38 million ha in 1930 to more than 90 million ha in 1983 and to 110 million ha in 2007. Rangelands now occupy 57\% of Mexico's territory and rain forest clearing to expand pasture continues to the present day in the states of Chiapas, Campeche, Quintana Roo, Oaxaca, Guerrero and Michoacan [16]. 


\subsection{Lack of National Climate Change Policies}

When it comes to carbon initiatives, a main challenge is the lack of clear national climate change policies, particularly those relevant to REDD+. Most governments are at the earliest stages of designing their policies for climate change mitigation and adaptation, and still lack clear directions on how to proceed on issues such as land use change and which government institutions-Ministry of Environment, of Forestry, Natural Resources, and so forth-will play the central roles in organizing REDD+ initiatives. Carbon initiatives are poorly integrated with broader policies related to land use and land use change. Most fundamentally, most countries have no clear definition of who will hold carbon rights and how carbon credits could be marketed once generated. In other situations, legislation may pose obstacles to REDD+ programs. For example, Ecuadorian regulations specify that all environmental services are not susceptible to ownership [15]. Those that avoid deforestation cannot claim property for the carbon services they continue to provide and therefore the way they could capture rewards under REDD+ may be open to question.

\subsection{In conclusion: Policy Barriers to Forest Governance and REDD+ Initiatives}

This review shows that faulty policies and regulations in the region are numerous and pose important barriers to the quality of forest governance.

- Forest policies, because of their complexity, abundance and compliance difficulties, can unintentionally promote deforestation and conversion of forest lands to other uses, predominantly agriculture and cattle ranching. These same weaknesses are likely to increase the costs of implementing REDD+ programs. Major policy framework revisions are probably needed in most countries.

- Policies and regulations in other sectors, particularly those governing infrastructure development, mining, oil and gas exploration and extraction, cause extensive deforestation and forest degradation as well as intense conflict with traditional populations. Despite the increased restrictions on paper that are supposed to compel these types of projects to include social and environmental safeguards, in practice these safeguards are often put into practice half-heartedly. REDD+ programs will need to ensure the effective application of safeguards against deforestation caused by the extra-sector policies, and this may considerably increase the transaction costs involved. Experience shows that the application of safeguards related to road developments, for example, are extremely difficult to enforce unless considerable human and financial resources are committed.

- Subsidies to promote the development of planted forests or embedded in low timber concession fees may also promote deforestation and forest degradation by encouraging conversion of forest lands to other uses or the wasteful exploitation of timber. In the same way, and particularly in those situations where land is relatively scarce, subsidies for cattle ranching or to promote agricultural production lead to deforestation and land use conversion. The elimination of subsidies in the forest sector is a politically difficult process as subsidies are frequently designed to favor a particular power group that naturally will fight their withdrawal, even if the subsidies can be shown to lead to increased deforestation. The political problems of tackling 
agricultural subsidies are probably even more intractable as agricultural lobbies in most countries tend to be more powerful than those associated with REDD+ initiatives.

- The practice of recognizing previously forested land now dedicated to alternative uses as a form of land "improvement" and as a condition for granting land tenure, although fast disappearing in most countries, has caused large-scale deforestation. REDD+ would need to eliminate perverse incentives to deforestation in those countries where they still operate.

- Uncertain land tenure and rights cause conflict and inducements to deforest. And as land cannot be used as collateral for forest investments, the lack of legal tenure tends to reduce the propensity to engage in long-term forest management and to increase the uncertainty of such investments. This is probably one of the most important obstacles faced by REDD+ as clear property rights to the carbon services provided by forests is a key element in attributing rights to rewards from avoiding deforestation.

- When it comes to carbon schemes such as REDD+, rather than an abundance of policies and regulations the opposite is true, with governments only now in the process of designing their climate change and carbon policies. This is one area where a policy vacuum still exists.

- Many other policy failures affect forests. The Annex succinctly presents some of the most relevant failures still present in some Latin American countries.

\section{The Rule of Law}

In view of the policy and legal failures described above, it would seem unavoidable that the rule of law would not be strong in many cases. Since in many instances legal regulations are impossible or very difficult to follow, forest operators are compelled to operate outside the law. However, obviously not all laws and regulations are flawed and certain activities, such as outright stealing of wood from public or private lands and harvesting timber in protected areas, are clearly undesirable criminal acts. The most important cases of breaking the law are related to the pervasive extent of illegal logging in most Latin American countries.

\subsection{Illegal Logging and Corruption}

The existence of illegal logging and illegal trade is a clear expression of poor governance in Latin American countries. Corruption, the abuse of public power to obtain illegitimate private gains, is often associated with, and facilitates, illegal logging. Corruption manifests itself in the form of bribes, extortion, kickbacks and protection money. Corruption facilitates practically all other illegal forest activities. Countries that are weak in controlling corruption are also those where deforestation is more intense. While the cause and effect relationship is hard to establish unambiguously, corruption does appear to contribute to deforestation [30-33].

Hard data on illegal activities and corruption are difficult to obtain, since these are always covert activities. Much of the existing knowledge is based on anecdotal information and local research. However, indirect measurement such as detecting discrepancies in international trade in forest products and surveys of perceptions provide reasonably good estimates of the magnitude and extent of forest crime. Various studies completed in the last few years suggest that illegal forest acts are common almost everywhere in the region. 
In Brazil, illegal logging estimates vary widely depending on the definition of what can be considered as "illegal" timber. The most reasonable estimates seem to be in the order of $20-47 \%$ of all extractions, with the major incidence in the Amazon Region [30]. Other assessments suggest that in 2007, 20-40\% of exports originating in logging concessions in the Brazilian Amazon may have been illegal under various criteria (economic crime, lack of forest management plans, and so forth). Given that Brazil has considerably strengthened law enforcement in the forest sector, more recent data would probably show lower levels of illegal logging.

In Peru, illegal timber was probably around $15 \%$ of the total harvest in 2005 but a much larger proportion, perhaps as much as 4\%, could have been "legalized" [34]. Surveys in two important extraction areas in the lowland humid forests (Ucayali and Loreto regions) revealed that $78-88 \%$ of respondents admitted seeing logs being extracted outside authorized areas and that $56-80 \%$ said that they had been requested to "launder" illegal logs by including them as part of their authorized volumes [35]. Another survey showed that while the law restricted small timber contracts on public lands to a maximum area of 1,000 ha per person, most logging companies typically held multiple contracts, thus securing as much as 10-times the 'maximum' area under their control. Contract holders openly recognized this fact, suggesting that there was very little fear of detection and ensuing punishment by government authorities. The same survey revealed that 625 small scale contracts, $39 \%$ of companies with multiple contracts and $14 \%$ of companies with large contracts, had never, in their history of contracting on public forests, been visited by inspectors from enforcement agencies [35].

Evidence from opinion surveys in Guyana show that illegal logging in this country may be in the 15-20\% range [17]. In Suriname, the percentage of illegal timber detected by government authoritiestimber seized or fines for non-compliance with regulations as well as "tolerated" timber on lapsed timber concessions - is around $10 \%$ of total production but the government estimates that an additional $20 \%$ of timber is probably illegal but goes undetected [12].

In Bolivia, up to 300,000 ha of forest are lost every year and about $70 \%$ of that is apparently due to illegal logging [36].

\subsection{Illegal Logging and Its Consequences}

The economic, environmental and social consequences of forest illegal activities are extensive and significant. Illegal logging often facilitates the conversion of forest lands to other uses. Unauthorized occupation of protected forest areas seriously threatens their biodiversity, soil and water conservation and carbon storage capacity.

Illegal extraction of forest products reduces their value, distorts markets and undercuts the operation of legitimate enterprises. For example, studies show that illegal logging may reduce international wood prices by as much as $7-16 \%$, thus substantially reducing the comparative profitability of legitimate enterprises [30]. Illegal logging also reduces potential government revenues that could be invested in sustainable forest management or general economic development [37]. Although it is sometimes argued that the rural poor who depend heavily on forests benefit from unauthorized acts, this benefit may be short-lived. Eventually the invasion of these forest lands by large loggers ends up seriously threatening the rural poor's access to forests. 
Other costs and negative impacts of illegal acts include the weakening of government institutions, the dissemination of corruption and the spread of a culture that not only tolerates but also actively seeks cooperative participation in illegalities [38]. When this happens, corruption spreads to other sectors of the economy. Timber is a bulky product and frequently it is transported from areas that are sparsely populated and with few roads. Therefore, illegal wood should not be very hard to detect even with relatively simple control systems. The fact that it is hard to detect suggests that staff from various other institutions besides the forest administration, including local politicians, the police and customs officers, simply ignore or willingly participate in facilitating illegal logging. As other actors are infected, it is not uncommon to observe illegal forest activities associated with other crimes such as money laundering and drug traffic [33]. In Colombia, for example, illicit forest activities are linked to deforestation associated with the expansion of banned drug crops in the Andean and Amazon regions. It is estimated that, on average, each hectare of illicit drug cultivation leads to 2-2.5 hectares of cleared forests [7].

\subsection{The Drivers of Illegal Logging}

Some technically illegal operations take place because of the policy failures described above, such as the inability of some forest actors to comply with cumbersome, complex and expensive regulations. Sustainable management and logging regulations are normally designed for standard, mainly large, forest operations without distinguishing the differential conditions of the various operators. Typically, legal logging operations need to be referenced to sustainable forest management plans approved by the relevant government agency. Management plans assume the capacity to carry out forest inventories, establish a calendar for harvesting based on projections of forest evolution, the definition of some harvesting technologies (such as Reduced Impact Logging) that may be required, and so on. In turn, such plans assume clear property rights sanctioned by government. Some smallholders and communities do not have the wherewithal to comply and thus unless they have external assistance they may opt to operate informally and in technically illegal conditions.

In other instances, illegal logging operations result from the inability of government institutions to detect and control illegalities, or their unwillingness to do so because of pervasive corruption. Weak forest institutions are common in countries where governance in general is not strong. In these cases, forest institutions are unable to detect forest crime, prosecute offenders and effectively enforce the law by imposing stiff penalties for criminal acts. Forest resources, particularly those that on paper are owned by government, are generally "open access", where the presence of public agencies to enforce ownership and the rule of law is not felt. The incentives to act outside the law are strong when illegalities are unlikely to be discovered, perpetrators unlikely to be prosecuted if discovered, and even if prosecuted and convicted are likely to get away with insubstantial penalties.

Financial incentives for illegal logging are also high because of their profitability. Illegal loggers do not have to pay taxes, stumpage fees and expenses for compliance with forest and environmental regulations. In Suriname, the price differential between legal and illegal timber can be as much as 35\%, suggesting that this is at least the magnitude of the lower costs of illegal logs [12]. A study in Nicaragua estimated that the total costs of complying with regulations was about $\$ 20$ per cubic meter with the process of obtaining permits taking some five months [39]. Other studies in Honduras, 
Nicaragua, Costa Rica, Chile and Bolivia show that the costs of legal wood can be quite sizeable [40-42]. And of course, if the probability of detection is low and penalties if caught insubstantial, then the incentives to operate outside the law are quite strong.

While this is far from certain, REDD+ could sufficiently alter the economic parameters of illegal logging to make abstaining from illegal deforestation an attractive option. By funneling funds to forest landowners who are able to keep their lands forested, the financial incentives to convert forest to other land uses could be overcome. However, while this could deter some types of illegal logging and deforestation, clearly other types of unauthorized land conversion would remain. For example, the illegal occupation of public forest lands is likely to continue or at least not be deterred by REDD payments because in these cases there is no legitimate owner to be compensated for their forest conservation efforts. In other cases, subsistence landowners living at the margins of the market economy may not be persuaded by the modest financial compensation that may be needed to cover their very low opportunity costs associated with abandoning their practices.

\subsection{Initiatives to Control Illegal Logging and Trade}

Various Latin American countries are implementing programs to control illegal logging, including Ecuador, Brazil, the countries of Central America and Peru. In Brazil's case, the strong drive to control illegal logging has been founded on strong political commitment, sophisticated monitoring systems and prompt verification of legality and law enforcement. In other cases, such as in Ecuador, attempts to improve law enforcement have been founded on political resistance from vested interests.

Some countries have attempted to increase the attractiveness of legal forest management to reduce the inducements for illicit logging. For example, in Bolivia, Brazil, Mexico and Guatemala, governments have promoted forest certification which, although it does not result in higher prices for wood and therefore higher financial returns, it has often helped to obtain and maintain access to some profitable markets.

Given that illegal logging and trade involves players from both forest resource rich countries and importing nations, and because illegal logging leads to the loss of global values, programs to control illegal logging and trade have been created by the international community to support efforts in exporting countries. Most of the above mentioned countries receive some form of support from these international programs.

The Forest Law Enforcements and Governance Program (FLEG) is a multi-donor partnership established at the World Bank to reduce illegal logging and curb the associated forest degradation and deforestation. The program supports various governance improvement activities, and has been instrumental in increasing awareness of the problem and fostering political support for action in various countries. It focuses mainly on supply side governance improvements in countries affected by illegal logging. In contrast, the European Union Forest Law Enforcement, Governance and Trade program (FLEGT) focuses on demand instruments - essentially imposing barriers to wood imports that cannot be proven to have legal origins-blended with supply side activities to discourage illegally sourced timber exports and favor lawful ones in the exporting countries. While FLEG has been active in several Latin American countries, FLEGT has mainly concentrated on Asian and African exporters to Europe. 
Programs to combat illegal logging have also been embedded in various bilateral agreements, for example between the US government and governments of countries in the region. In 2008, the U.S. also amended its Lacey Act to prohibit trade in illegally sourced plants, including timber. Several other importing countries are considering similar legislation. Because the main market for most Latin American exporters is the US, the Lacey Act is likely to have a more intense impact than FLEGT, which is focused on the European market.

\subsection{In Conclusion: Illegal Acts, the Quality of Forest Governance and REDD+}

The inability to deal with illegal logging is a significant barrier to improved governance, including the execution of REDD+ forest carbon programs that require an unambiguous assurance of additionality and permanence of reductions in deforestation and forest degradation. The failure to control illegalities would undermine REDD+ programs, which rely on strong government institutions and effective control of illegal logging and unauthorized land conversion.

While the international processes to control illegal logging described above, such as FLEG, are not specifically aimed at satisfying the specific demands of REDD+, their purposes are mutually consistent. And so are most of their programmatic elements. For example, both REDD+ and FLEGT initiatives emphasize the need to rationalize the policy framework governing the sector, rely on rather precise monitoring systems to track alterations to the forest mass and require much better definition of property rights. There is, therefore, an opportunity for developing strong synergies between these two types of initiatives. However, a systematic linkage between forest law enforcement initiatives and REDD+ still needs to be developed.

If REDD+ initiatives impose new governance demands on countries, these initiatives may also provide a push for addressing illegal forest activities. REDD+ performance-based financing could alter the economic parameters in favor of increased legality and thus provide incentives to reduce illegal deforestation, unauthorized forest conversion and forest degradation. While this is true, REDD+ programs could also work in the opposite direction. Unless robust safeguards are in place, a real danger is that the large flows of funds REDD+ programs could bring would also open new opportunities for corrupt behavior and for elite capture of the financial benefits that these programs could generate. The increased value of forested lands could also reinforce the tendency of commercial interests and governments to deny or ignore the rights of forest dependent people and communities with traditional claims to those lands.

\section{Government Effectiveness}

Obstacles to quality forest governance are present when the quality of government institutions, their civil service and policy formulation and implementation are poor, and the credibility of government commitment to such policies is low [43].

\subsection{Overall Government Effectiveness}

As the quality of governance in the forest sector depends on the actions of multiple agencies at different levels of government-from the parliament issuing laws, to the forest service having 
responsibility for direct management of the sector, to the police and judiciary implementing laws and regulations - the quality of forest governance is inevitably associated with the quality and effectiveness of government in general. The quality of overall governance is also extremely relevant in the execution of REDD+ programs as their nature is multisectoral, involving multiple government institutions at various levels, national and subnational, as well as effective institutional links with other actors.

Indicators of general government effectiveness, measuring various dimensions and aggregated by the World Bank "Governance Matters" program, are available for a number of countries of the region. These indicators show that government effectiveness varies widely (see Figure 1). The quality of sector governance and effectiveness is likely to be problematic in those countries at the bottom of the list. It is reasonable to expect that barriers to improved forest governance will be the greatest in these countries.

Government effectiveness can be measured by government commitment to apply its own norms, the capacity of government institutions to govern the forest sector, including its ability to monitor developments, and the effectiveness of the action in relation to government national strategies and its translation into real action by different government levels and agencies. These dimensions of government effectiveness are discussed below.

Figure 1. Government Effectiveness Index (2008) (Adapted from [43]).

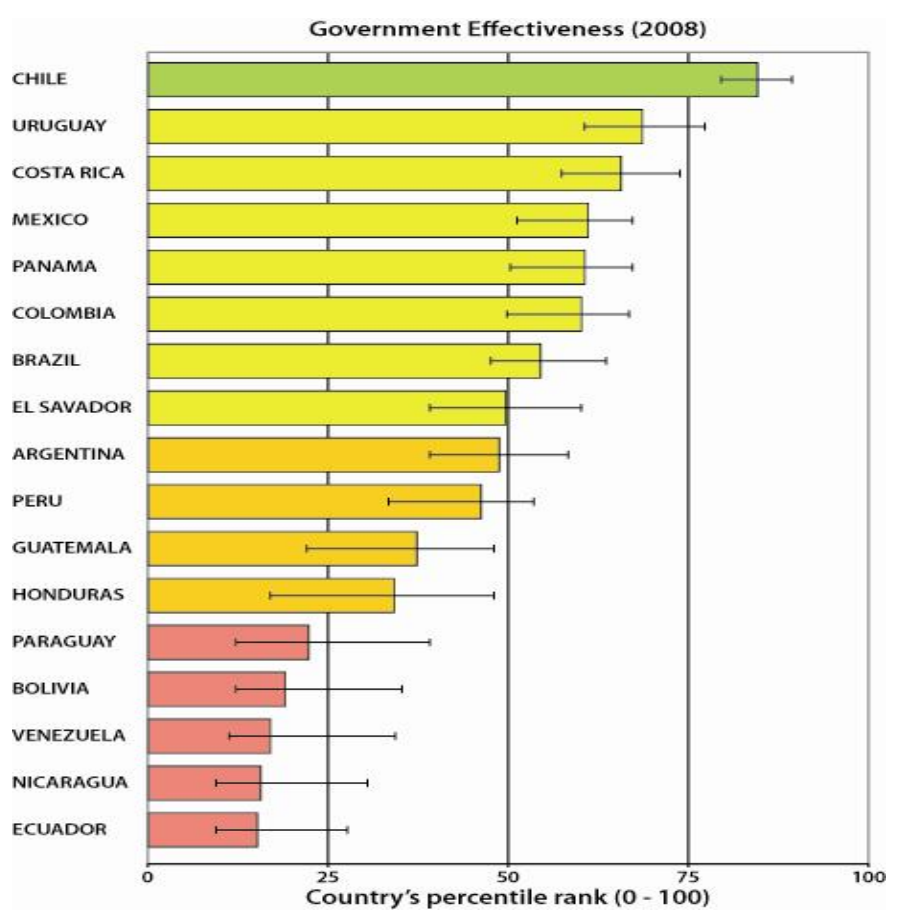

\subsection{Government Commitment}

The strength of a government's commitment to actually apply its own norms can be questioned in many cases. In Peru, for example, national government forest staff routinely ignore regulations that require them to establish coordinating mechanisms with other national, regional and local authorities in granting permits to individuals and firms for developing infrastructure and other works. Further, environmental management regulations are considered as an inconsequential requisite in granting licenses, as is civil society participation in these decisions. With the Forest and Wildlife Law and its regulations approved at the beginning of the decade, there was a renewed attempt to develop a new 
model for managing these resources and including procedures for access to public forests. However, these norms appear to have been largely ignored and considered only as an inconsequential requirement rather than as an effective instrument to promote the adequate utilization of forest resources in timber concessions. In these circumstances, illegal logging and the expansion of an "informal" economy has been allowed and promoted [23]. Evidently, a lack of government commitment spells out problems for the effectiveness of REDD+. If, for example, environmental safeguards related to road-building in forest areas are ignored and not fully enforced, the inducements to deforestation will remain unaltered.

\subsection{Capacity of Government Institutions}

In various countries, the capacity of government institutions is very limited compared with their responsibilities. Institutions entrusted with forest management often have low operational capacity in terms of capable personnel and equipment. In Suriname, for example, 55 officers were engaged in controlling and monitoring widely dispersed forest operations in 2007. Thus, although the government's timber control system - Foundation for Forest Management and Control, SSB — means it should be possible to track individual logs, in practice the shortage of SSB staff and uncertain funding means controls are limited only to the most obvious and visible cases. Border trade with Guyana, for example, can easily go undetected due to uneffective border controls. Coordination with the police is imperfect, which complicates law enforcement [12]. Further, the government has virtually no control over illegal gold mining in forest areas. In 2005, the government registered only 10 gold legal mining concessions, while in reality there were probably some 10,000 such operations. While there are no precise data on the extent of forest lost to illegal small-scale gold mining operations, it is estimated that some 20,000 hectares have already been deforested as a consequence [12].

The Nicaraguan Forest Service office in Puerto Cabezas municipality has a total staff of only one officer, two assistants and a secretary. Transportation depends on a single motorcycle. This team is responsible for a territory of 1.5 million ha. This includes, among other things, monitoring how the forest is being used, comparing this with permits issued, gathering evidence when discrepancies are found, impounding equipment used in illegal operations, apprehending criminals and initiating legal procedures against them. Evidently, such a small and poorly-equipped team has no capacity to even monitor what is happening in this vast area, let alone enforce the law. This weak team also faces well-armed forest operators who have few scruples in using force to impose their way [41].

In Peru, with a limited technical and legal staff, the Organismo Supervisor de los Recursos Forestales Maderables (OSINFOR) has been able to supervise an average of 50 timber concessions per year, only $10 \%$ of the 510 concessions in operation [44].

Further, technical capacity is also not generally available in those government agencies that are not "forest agencies", but have an effect on forest management, such as agriculture, mining or infrastructure development agencies. It has also been observed that where technical capacity has been created in either forest or forest-related agencies, often it has later been lost because of the rapid turnover of government staff [15].

The limited capacity of government institutions is particularly acute in implementing forest carbon initiatives, as very little experience has accumulated in most countries. Further, the technical capacity 
needed to implement REDD+ is still evolving, as the REDD+ architecture is still not fully agreed. Capacity will need to be created according to these evolving demands and this is a difficult task in situations where the pool of professional staff is small.

\subsection{Monitoring Forests}

In some countries, some substantial investments have been made in installing forest inventory systems and monitoring forest developments (notably Brazil), but few others regularly monitor forest cover systematically. [9] reports that of the Mesoamerican countries (Mexico, Belize, Costa Rica, El Salvador, Guatemala, Honduras, Nicaragua, and Panama), only Costa Rica is approaching systematic monitoring of forest resources.

In Brazil, reductions in deforestation in the Amazon and illegal logging have been based on a near real-time forest resources monitoring system, which is both accurate and transparent. Brazil's National Space Research Institute uses four different sensors to monitor deforestation: PRODES which, using high resolution analysis, detects annual deforestation; DETER, a mid resolution system that provides monthly estimates of deforestation over 25 ha and thus provides the basis for enforcement; DEGRAD, which estimates yearly degradation; and, a system that provides daily monitoring of forest fires using NOAA and other low resolution satellites.

This efficient monitoring system has been credited with facilitating faster responses to deforestation pressures and for reducing the magnitude of illegal logging. For example, when commodity prices increased in 2007, presaging an increase in pressures to deforest, government staff were alerted in time to design a counterbalancing policy response. Deforestation still increased in 2008 but was kept below historical levels, suggesting that while the link between commodity prices and deforestation has been weakened, it has not been broken altogether. Further, figures for 2009 indicate a further substantial drop in deforestation in the Amazon. Again, while some of this drop can be attributed to fluctuations in world commodity prices, there is little doubt that tighter monitoring and prompt law enforcement by the government has made a substantial difference in controlling illegal logging and conversion of forest lands to other uses [45].

Unfortunately, the Brazilian case is rather unique in the region. Other countries do not employ such a sophisticated and effective forest monitoring system and therefore are crippled in designing appropriate responses to threats to forest resources.

Close monitoring of the evolution of forest resources over time is one of the most fundamental elements of REDD+ programs, which need to ascertain to what extent deforestation and forest degradation is actually being reduced as a consequence of these programs. Therefore, unless the forest monitoring, reporting and verification systems in place are effective and credible, it will not be possible to adequately construct a REDD+ mechanism.

\subsection{National Development Strategies and Coordination between Agencies}

A main forest governance challenge is the imperfect alignment of various policies with an effect on forests. In operational terms this translates into insufficient coordination and harmonization between government institutions horizontally as well as between the different government layers-central, provincial or state, and local. 
The harmonization of forest governance initiatives, including REDD+ programs, with national development strategies such as rural development and poverty alleviation, is generally less than adequate, which makes it difficult to effectively deal with the major deforestation drivers outside the forest sector. As mentioned, national climate change strategies have yet to be formulated in many countries and this is also the case with REDD+ strategies. As mentioned earlier, the fact that forest strategies and policies may need to be reformed to eliminate their many failures has made it difficult to harmonize policy frameworks.

This generally translates into a weak harmonization of action between government agencies that have an effect on forests and between national or central and local levels of government. Government effectiveness is seriously hampered by the failures of government agencies to act in a consistent and concerted fashion. Most agencies tend to operate as separate entities working in isolation on the same piece of land over which they have jurisdiction. A ministry could be encouraging the implementation of a REDD+ initiative in a certain area while at the same time another ministry could be planning new roads in the same area.

The same is common in the coordination between layers of government. In Brazil, three government levels — federal, state and municipal — have powers over environmental management and in some cases they can wield conflicting authority over the same environmental matter. The Brazilian Constitution sets out the responsibilities of the tiers of government in matters related to environmental protection but a lack of clarity in respect of institutional assignments results in many conflicts and judicial disputes, particularly when implementing relatively new initiatives such as forest carbon programs [45].

\subsection{The Institutional Demands of REDD+}

The success of implementing REDD+ programs is heavily dependent on the capacity of government institutions to create adequate incentives for numerous actors at multiple levels-international, national, private entities and forest landowners and users, as well as indigenous peoples and forest dependent communities - to actually address the underlying causes of deforestation. While there is an intense on-going discussion on how to best practice this, including national and nested approaches for example, the architecture of implementation schemes is quite complex in all cases. Effective carbon accounting systems, incentives schemes that adequately, quickly and fairly reward those that actually move away from deforestation and forest degradation depend on the capacity of institutions, public and private, to function at a reasonable level of efficiency and effectiveness. REDD+ programs are complex and, in the final analysis, much depends on the effectiveness of government institutions to implement programs of a notable scale and with degrees of complexity and demands for transparency that they have never faced in the past.

\subsection{In Conclusion: Barriers to Government Effectiveness and to REDD+ Implementation}

The limited general government effectiveness in some Latin American countries creates significant barriers to forest governance and to the possibility of implementing effective REDD+ initiatives. This is because the quality of forest governance depends on strategies, policies and institutions in other sectors beyond forests but that have a strong influence on how forests are managed. In some countries, governance failures are reflected in the lack of strong government commitment to effectively 
governing the forest sector, with government institutions failing to enforce their own rules in many cases. In other instances, effectiveness is hampered by the incapacity of government agencies to monitor what actually happens in the sector, to track its evolution and the causes of changeknowledge that is critical for the effective implementation of REDD+ programs. Inadequate policy harmonization often leads to poor horizontal coordination of government institutions that directly or indirectly have a strong impact on forest management and the execution of REDD+ programs. In some instances, the policies and actions of national governments are poorly coordinated with those at the subnational, provincial, state and local level.

\section{The Political Economy of Governance Reform}

While some of the obstacles to forest governance discussed above could be reduced by introducing well thought-out policy and institutional reforms, this is usually easier said than done. In fact, in various parts of the region, efforts are underway to reform forest governance to deal with the obstacles. However, often the sector's governance has remained stubbornly resistant to needed change.

Governance reforms entail sound analytical work to ensure adequate design, including an analysis of the political costs and benefits associated with potential changes, and forming coalitions to support and sustain their introduction. Governance reforms in the forest sector entail harnessing public opinion, dealing with interest groups and overcoming inertia in public institutions. These obstacles have been dealt with only partially in most cases.

The difficulty in forming coalitions to overcome resistance to reforms seems to be one of the main reasons for forest reform failure. Reform, to succeed, needs to be politically desirable, feasible and credible. Political desirability means that key actors, not only government, support governance reform. Feasibility implies securing the support of other government entities - such as the legislature, state and provincial governments-whose cooperation is critical to success. Reforming agencies must also be able to withstand the opposition of potential losers. Credibility refers to the political commitment of government for sustaining forest reforms.

\subsection{Analytical Work}

Designing successful forestry governance reforms requires a good knowledge of the political economy that motivates and shapes changes. It requires a clear understanding of the capacities and motivations of government institutions, staff and the private sector, and how dialogue between the main stakeholders takes place.

However, regulatory and institutional reform is often plagued by the relative weakness of forest government institutions to identify what is wrong with the sector's governance and how it could be changed. When these analyses are carried out, they tend to focus on technical matters rather than the political consequences of reform. For example, most analyses have commonly ignored the complexities of local situations and the interface between formal rights to access and control resources, and those of a more informal nature that are not codified in norms and regulations. Since formal rules normally favor the powerful and politically connected, it is not surprising that those with limited resources to satisfy norms are likely to actively resist them and choose instead to operate in the informal economy. Analytical work providing the intellectual foundations for governance reforms will 
almost always be faulty if it fails to detect these differences between formal and informal rules and practices. Analytical work underpinning forest reforms also normally fails to assess winners and losers, which later will define the political alignment of forces that will approve, modify or fight governance changes.

The failure to integrate political economy considerations in some cases has been partially handled by securing international assistance and political economy expertise to complement national reform efforts. International expert advice is, in some cases, regarded as less compromised and therefore more impartial than advice from national institutions, which are instead frequently perceived as aligned with government, private sector or other interest groups. In Bolivia, for example, the World Bank supported several studies analyzing options for reorganizing the sector, FAO contributed with data and various technical analyses and USAID lent welcome support to various analyses of the various elements of the legal reform and ways to align the various and conflicting interests.

All this contributed to a reasonably solid framework for the substantial governance reforms that followed in the late nineties [46].

\subsection{Political Desirability}

Technical solutions alone, even if they may be excellent, are often insufficient. Much expert advice is never translated into effective action. Beyond being technically sound, reforms, to be successful, must be backed by a coalition of stakeholders and interest groups. Inevitably, sector reforms will hurt some groups, which then naturally will tend to oppose them. Therefore, reformers must necessarily dedicate considerable time and effort to analyzing the structure of power groups likely to influence the approval and implementation of governance initiatives.

It should be noted that often it is not only national stakeholders that matter. Occasionally, foreign stakeholders may wield considerable influence through, for instance, their trade policies. A case in point is the US-Peru Free Trade Agreement, which includes binding rules to strengthen the policy and institutional framework of Peru's forest sector. Since the potential for Peruvian exports to the US is considerable (estimates suggest that exports could increase by as much as $\$ 4$ billion under the Treaty), the forest sector rules in the agreement carry considerable weight. Also, the 2008 Amendment to the US Lacey Act includes provisions to outlaw the importation and trade of illegal timber. In the same vein, the European Union Forest Law Enforcement and Trade program seeks to restrict European markets to imports of legal wood only.

Regulatory and institutional reforms are unlikely to survive parliamentary debates and behind-thescene deals among power groups, unless the inevitable resistance of those that are bound to lose if the reforms are approved is overcome. In the case of the Bolivian governance reforms, significant discussions took place in a democratic manner in order to achieve a closer alignment with interest groups. Even so, reforms ran into problems, as some powerful vested interests could not be fully accommodated. While it was known that timber concessionaires would be among the clear losers and therefore were likely to resist changes, planners unfortunately did not have a clear idea of exactly how the reforms would affect the concessionaires' profits and the intensity of their anticipated opposition. Timber fees were applied to concessions but there was much heated discussion, unfortunately with little analytical support, around what the right level should be. Also, what would happen if 
concessionaires failed to pay these fees was imperfectly perceived. This was not inconsequential, as the fees collected were supposed to finance parts of the supervisory functions of government and other programs created by the reform process. Timber concessionaires predictably resisted the new regulations and refused to (or could not) pay the fees established by the new policies. To make matters worse, when some concessionaires failed to comply, the government was reluctant to cancel their concessions as provided by the law, thus reducing the credibility of its actions. Eventually, timber fees had to be modified (Box 5).

\begin{abstract}
Box 5. Forest governance reform in Bolivia: political desirability, feasibility and credibility.
After an intensive and long process of analysis and public consultation, a new "Regimen Forestal", including a new legal framework and changed institutions, was put in place in the mid-nineties. The success in getting a new policy and legal framework to reform forest sector governance was facilitated by a favorable political environment for reform and the successful alignment of various power groups with the reforms.
\end{abstract}

At the time, the Legislature modified the Constitution and approved several laws that had an influence on forest resource management. For example, an Environment Law prescribed that an authority should regulate the use of forests and produced several norms aimed at regulating the private sector. There was also a significant push towards decentralization and the recognition of the traditional rights of indigenous peoples and local communities. An Agrarian Reform Law was also approved that had great importance for the future Forest Law, which in many respects depended on clarifying land rights. These various reforms, and others, created a complex web of institutional interactions and increased the need for a new system for forest resource management.

In addition, reformers strived for a political alignment with main power groups. This was largely secured after intense consultation with the main stakeholders over 4 years, integrating a wide range of participants that would previously have been excluded from the political debate. Local governments were granted new powers. Local Community Associations (ASL) were formed to integrate forest-dependent communities into the decisionmaking processes; members came from traditional forest users, peasant communities and indigenous groups until then ignored and condemned as illegal operators. The new Regimen Forestal also recognized the exclusive right of indigenous communities to use their ancestral lands. Even individual citizens acquired the right, armed with warrants granted by the Forest Superintendency, to inspect forest operations. Thus, a broad coalition of interests was created to support forest governance reforms.

If there was a power group that did not clearly benefit from the reforms, it was the timber concessionaires whose operations became restricted on public lands. Timber fees were imposed in transparent ways that closed the opportunities for corruption. The fees were used to finance activities of the Forest Superintendency, the ASLs and local governments.

However, this is where things began to unravel. Disputes about the levels of the timber fees and the outright refusal by some concessionaires to pay fees at all, together with the Superintendency's reluctance to cancel concessions, undermined the government's credibility and finally led to one of the Regimen Forestal's key foundations collapsing. Subsequent political changes have added new uncertainties to the governance reform process.

Source: [46]

In Ecuador, a small and exclusive group designed the governance reforms. Notable for their absence were indigenous peoples and private forest owners, which together controlled the majority of the forests. These actors eventually either became insufficiently supportive of the reforms or openly opposed them (See Box 6). As in Bolivia, forest industrialists did participate in developing the system but despite declaring their support for the reforms, in fact they opposed them. Again, these were among the "losers" of the new system and, in absence of compensatory or incentive mechanisms that could 
have facilitated the transition to the reformed governance system, their political support was lost and the reforms defeated.

Box 6. The political economy of reforming forest governance in Ecuador.

In 1999, after a national participatory process, the Ecuadorian Government issued a new Forest Policy. It was then recognized that transparency and accountability in forest operations were essential to good governance of the sector. The Ministry of Environment issued Standards for Sustainable Forest Management, which allowed the forest authority to monitor logging activities. Then the government established the Outsourced Forestry Supervision System (Sistema Nacional Tercerizado de Control Forestal, SNTCF) to combat illegal logging. The SNTCF delegated certain administrative and supervisory duties of the Ministry to private actors, with the purpose of increasing transparency and providing mechanisms for cross checking operations that would improve the quality of governance.

The SNTCF structure comprised the Green Surveillance (Vigilancia Verde), an organization under the Ministry of Environment that included representatives from the armed forces, the Police and five NGOs and was responsible for controlling transport of logs; and the Forest Steward (Regencia Forestal) program that allowed professional foresters authorized by the Ministry of Environment to ensure that authorized harvesting activities were following the forest management plans and to fill out transport permits in the forest. The Ministry of Environment also outsourced its administrative and verification responsibilities to a private company which under competitive tender turned out to be the Ecuadorian branch of the Swiss-based firm SGS, which was allowed to collect fees for its services from forest users or loggers.

During its short period of operation, the SNTCF was successful in controlling various types of illegality. In its first year, the volume of illegal logs seized was five-times that of previous years. The system also was initially successful in curbing corruption and the undue influence of powerful vested interests in government forest institutions.

The system came to a halt when its constitutionality was challenged by the forest industry. Many believed that the outsourcing of public duties to private entities was possible under the Constitution and the State Modernization Law of 1993. However, the Constitutional Tribunal ruled in 2003 that outsourcing services to SGS and its practice of collecting fees for its services were unconstitutional. Promptly, the Ministry of Environment reclaimed all responsibilities previously outsourced to SGS, throwing one of the SNTCF pillars into disarray. In retrospect, the low political desirability and feasibility, as well as the limited credibility of the Ecuadorian governance reform, were all likely to cause the reforms to fail.

Source: [47]

\subsection{Political Feasibility}

In the Bolivian case, the cooperation of other government agencies was politically desirable. Some initiatives that required forest sector reforms were initiated in other parts of the government. In Ecuador, while the cooperation of other government agencies was to some extent secured, political support within the Ministry of Environment itself was largely absent. Whereas reforms had originated with a few highly qualified senior Ministry officials, hundreds of staff became hostile when they realized that informal benefits generated by the old system could be lost. Again, had the reforms provided for some kind of inducement for staff to go along with the dramatic change in their functions, the chances of success would have increased. Also, had other Ministries with staff without a stake in maintaining the status quo been involved in the scheme, it is possible that a critical mass of institutional support could have been created to counterbalance the internal resistance at the Ministry of Environment [47]. 
In Brazil, the Action Plan for the Prevention and Control of Deforestation in the Legal Amazon was conceived by the Ministry of Environment but gained considerable political support both in government and the public. The Presidential office was entrusted with coordinating the Action Plan. The office established impressively effective linkages to 13 other ministries as well as the Federal Police, the Federal Highway Police and the armed forces. Initially, the political opposition to implementing the plan was intense, but support from the highest levels of government was sufficient to overcome resistance from vested interests. While the Minister of Environment at one point stepped down, the policy itself remained in place [48].

\subsection{Credibility}

As mentioned, the credibility of government reforms was seriously strained in Bolivia when the Forest Superintendency did not cancel timber concessions where timber fees had not been paid. The same happened in Surinam when the government failed to close timber concessions that had expired and were instead "tolerated" and allowed to continue operations. In Peru, the government was compelled to reverse policies when indigenous people violently objected to their traditional lands being allocated to mining, gas and oil concerns. In all these cases, morally defensible or not, the fact is that the wavering commitment of government to impose its own policies, in practice cancelled them.

\subsection{In Conclusion: The Importance of Understanding the Political Economy of Reform}

Efforts to eliminate the barriers to forest governance and to effectively implement complex programs such as REDD+ will require sometimes drastic policy and institutional reforms. However, beyond being anchored on sound technical rationale, reform attempts will more than likely be opposed by those that lose from the changes. Experience shows that typically the approval of forest laws and other major forms of legislation takes years of discussions and political wrangling, with the final results often bearing only a minor resemblance to the original reform proposals.

Reformers must therefore understand the political landscape and how proposed changes would negatively impact on the interests of key groups that could challenge those changes, and design strategies to thwart or at least deflect resistance by these vested interests. These strategies are diverse, ranging from expanding political support by intensifying communication with the general public, to stiffening the resolve of government agencies that may support reforms through better communication and more intense operational institutional linkages, organizing broader consultative discussions on the issues involved, or devising ways to somehow compensate losers either financially (for example, REDD+ schemes would pay those that abstain from deforesting) or by other means (such as increasing the security of land tenure, or the stability of long-term timber contracts).

\section{Final remarks}

The adequate management of forest resources in countries of Latin America is hampered by a number of barriers. Faulty policy and regulatory frameworks that make sustainable forest management practices difficult or outright impossible to implement are common. Often, regulatory frameworks introduce incentives to deforestation and to the conversion of forests to other uses. Policies in related 
sectors also frequently introduce strong pressures and inducements to engage in unsustainable forest practices. Complex and faulty regulatory environments, the weakness of enforcement institutions, the high rewards, low levels of risks and punishment and the presence of corrupt practices encourage illegal logging in many countries. Adequate levels of governance in the sector are also hindered by the general weakness of government institutions, which are generally unable to assess the extent and quality of forest resources, monitor their evolution to detect undesirable practices and impose the rule of law. Policy, regulatory and institutional reforms aimed at improving forest governance are possible but this has proven to be a difficult endeavor, firstly because particularly those needed to satisfy the demands of REDD+ programs must be quite broad, entailing changes in related sectors as well as in the forestry sector. Secondly, because they are bound to create intense political opposition from interest groups that benefit from the status quo and therefore see their condition threatened by the reforms.

There are few examples of successful, long lasting, forest governance reforms in the region. They are concentrated in a few countries (for example, Brazil), are relatively recent (Brazil, Peru), many cover a partial number of the wide array of governance issues that require reform (Bolivia, Ecuador) or have been undermined (Bolivia) or even turned back by interest groups opposing them (Ecuador). The implementation of REDD+ programs is providing a strong incentive for countries to eliminate barriers to forest governance and at least some of the reforms now introduced are clearly spurred by these programs. It is reasonable to expect that REDD+ incentives will only strengthen this trend.

The experience gained by some countries of Latin America in the operation of Payments for Environmental Services (PES) programs is valuable in constructing the required REDD+ schemes. Costa Rica, for example, has a PES program started in 1996 to protect and regenerate natural forests and to promote the development of forest plantations. The region is also a leader in implementing Payments for Watershed Services programs with 36 active such programs in 2008. Cases in Ecuador, Colombia, Brazil and Peru use these schemes to pay for upstream conservation. From 1994, Mexico operates a project in Chiapas that provides technical assistance and financial support to help some 700 farmers to capture carbon revenues. These and other experiences provide valuable know-how for other countries to learn.

\section{References}

1. Saunders, J.; Nussbaum, R. Forest Governance and Reduced Emissions from Deforestation and Degradation (REDD); Energy, Environment and Development Programme; Royal Institute of International Affairs: London, UK, 2008.

2. Schmithüsen, F. Cross sector linkages related to sustainable forest management, policy and legal aspects. Technical Meeting on Cross Sector Policy Impacts Between Forestry and Other Sectors; Food and Agriculture Organisation of the United Nations: Rome, Italy, 2002.

3. Miller, T.; Holmes, K.R. Index of Economic Freedom; The Heritage Foundation: Washington, DC, USA, 2010.

4. World Bank and International Finance Corporation Doing Business 2010 Suriname; The World Bank: Washington, DC, USA, 2009.

5. World Bank and International Finance Corporation. Doing Business in Colombia 2010; The World Bank: Washington, DC, USA, 2010. 
6. Djankov, S.; La Porta, R.; Lopez-de-Silanes, F.; Shleifer, A. The regulation of entry. Quar. J. Econ. 2002, 117, 1-37.

7. Deforestación Evitada. Una Guia REDD+ Colombia. Ministerio de Ambiente, Vivienda y Desarrollo Territorial; Conservación Internacional Colombia; Fondo Mundial para la Naturaleza (WWF); The Nature Conservancy; Corporación Ecoversa; Fundación Natura; Agencia de Cooperación Americana (USAID); In Patrimonio Natural_Fondo para la Biodiversidad y Áreas Protegidas y Fondo para la Acción Ambiental; Ortega, S.C., Garcia-Guerrero, A., Ruiz, C-A., Sabogal, J., Vargas, J.D., Eds.; Bogotá: Colombia, UK, 2010.

8. Del Gatto, F. La Produccion Forestal no Controlada en Honduras. Qué es Cuánto Cuesta. Unas Respuestas Preliminares. Consultant Report; Red de Manejo del Bosque Latifoliado de Honduras (REMBLAH): Tegucigalpa, Honduras, 2002.

9. Kaimowitz, D. The prospects for reduced emissions from deforestation and degradation (REDD) in Mesoamerica. Int. Forest. Rev. 2008, 10, 485-495.

10. Boscolo, M.; Vargas Rios, M.T. Forest law enforcement and rural livelihoods in Bolivia. In Illegal Logging: Law Enforcement, Livelihoods and the Timber Trade; Tacconi, L., Ed.; Earthscan: London, UK, 2007.

11. Scherr, S.; White A.; Kaimowitz, D. A New Agenda for Forest Conservation and Poverty Alleviation: Making Markets Work for Low-Income Producers; Forest Trends: Washington, DC, USA, 2004.

12. Playfair, M. Law Compliance, and Prevention and Control of Illegal Logging Activities in the Forest Sector of Suriname; The World Bank: Washington, DC, USA, 2007.

13. The State of the World's Forests 2009; Food and Agriculture Organisation of the United Nations: Rome, Italy, 2009.

14. Cotula, L.; Mayers, J. Tenure in REDD Start Point or Afterthought? Natural Resources Issues No. 15; International Institute for Environment and Development: London, UK, 2009.

15. Harvey C.A.; Zerbock O.; Papageorgiou S.; Parra A. What is needed to Make REDD+ Work on the Ground? Lessons Learned from Pilot Forest Carbon Initiatives; Conservation International: Arlington, VA, USA, 2010.

16. Enriquez, S. Assessment of Tropical Forest and Biodiversity Conservation in Mexico; Report prepared for the United States Agency for International Development; United States Agency for International Development: Washington, DC, USA, 2009.

17. Trevin, J.; Nasi, R. Forest Law Enforcement and Governance and Forest Practices in Guyana; CIFOR: Bogor, Indonesia, 2009.

18. Contreras-Hermosilla, A. The Underlying Causes of Forest Decline; CIFOR occasional paper 30; CIFOR: Bogor, Indonesia, 2000.

19. Soares-Filho, B.S.; Nepstad, D.C.; Curran, L.; Cerqueira, G.C.; Garcia, R.A.; Ramos, C.A.; Voll, E.; Mcdonald, A.; Lefebvre, P.; Schlesinger, P.; Mcgrath, D. Cenários de desmatamento para Amazônia. Estudos Avançados 2005, 19, 137-152; Available online: http://www.scielo.br/ scielo.php?script=sci_pdf\&pid=S0103-40142005000200008\&lng=en\&nrm=iso\&tlng=pt (accessed on 14 November 2010). 
20. Laurance, W.F.; Goosem, M.; Laurance, S.G.W. Impacts of roads and linear clearings on tropical forests. Trends Ecol. Evol. 2009, 24, 659-669.

21. Martins, O.S.; Moutinho, P.; Rettmann, R.; Pinto, E.P.P. Brazil. In REDD, Forest Governance and Rural Livelihoods; The Emerging Agenda; Springate-Bagiski, O., Wollenberg, E., Eds.; CIFOR: Bogor, Indonesia, 2010.

22. Amor-Conde, D.; Burgues, I.; Fleck, L.C.; Monterola, C.; Reid, J. Análisis Ambiental y Económico de Proyectos Carreteros en la Selva Maya. Un Estudio Regional; Serie Técnica 10; Conservation Strategy Fund: Arcata, CA, USA, 2007.

23. Dourojeanni, M.; Bandariarán, A.; Dourojeanni, D. Amazonía Peruana en 2021; Pronaturaleza: Santiago de Source, Perú, 2009.

24. Finer, M.; Jenkins, C.N.; Pimm, S.L.; Kane, B.; Ross, C. Oil and gas projects in the western Amazon: Threats to wilderness, biodiversity, and Indigenous peoples. PLoS ONE 2008, 3, e2932.

25. The End of the Hinterland: Forests, Conflict and Climate Change; Rights and Resources Initiative: Washington, DC, USA, 2010.

26. Brack, D. Controlling illegal logging: Consumer-country measures. In Chatham House Briefing Paper; Chathem House: London, UK, 2010; Available online: www.illegal-logging.info/ item_single.php?it_id=875\&it=document (accessed on 20 May 2010).

27. Bull, G.; Bazett, M.; Schwab, O.; Nilsson, S.; White A.; Maginnis, S. Industrial forest plantation subsidies: Impacts and implications. Forest Policy Econ. 2006, 9, 13-31.

28. Southgate, D. Policies contributing to agricultural colonisation of Latin America's tropical forests. In Managing the World's Forests: Looking for Balance between Conservation and Development; Sharma, N., Ed.; Kendall/Hull Publishing: Dubuque, IA, USA, 1992.

29. Angelsen, A.; Kaimowitz, D. When does technological change in agriculture promote deforestation? Presented at the AAEA International Conference on Agricultural Intensification; Economic Development and the Environment: Salt Lake City, UT, USA, 31 August-5 July 1998.

30. Illegal Logging and Global Wood Markets: The Competitive Impacts on the US Wood Products Industry; Seneca Creek Associates and Wood Resources International: Washington, DC, USA, 2004; Available online: http://www.illegal-logging.info/uploads/afandpa.pdf (accessed on 1 July 2010).

31. Koyuncu, C.; Yilmaz, R. The impact of corruption on deforestation: A cross-country evidence. J. Dev. Areas 2009, 4, 213-222.

32. Irland, L.C. State Failure and Corruption: Challenges for Forest Policy; ITTO Tropical Forest Update 19/1; ITTO: Yokohama, Japan, 2010; pp. 3-6; Available online: http://www.itto.int/en/tfu/id=2250 (accessed on 20 May 2010).

33. Kishor, N.; Damania, R. Crime and justice in the garden of Eden: Improving governance and reducing corruption in the forest sector. In The Many Faces of Corruption: Tracking Vulnerabilities at the Sectoral Level; Campos, J.E., Pradhan, S., Eds.; The World Bank: Washington, DC, USA, 2007.

34. Maroni Consultores SAC. Analisis Preliminar Sobre Gobernabilidad y Cumplimiento de la Legislacion del Sector Forestal en el Peru; The World Bank: Washington, DC, USA, 2006. 
35. Smith, J.; Colan, V.; Sabogal, C.; Snook, L. Why policy reforms fail to improve logging practices: The role of governance and norms in Peru. Forest Policy Econ. 2006, 8, 458-469.

36. Bolivia Forestal 2010 El Deber: CFB Alerta por Reduccion del Concesiones Forestales; Camara Forestal de Bolivia: Santa Cruz, Bolivia, 2010.

37. Kishor, N.; Oksanen, T. Combating illegal logging and corruption in the forestry sector. In Environmental Matters Annual Review July 2005-June 2006; The World Bank: Washington, DC, USA, 2006.

38. World Bank. Strenghtening Forest Law Enforcement and Governance: Addressing a Systemic Constraint to Sustainable Development; Report 36638 GLB; Sustainable Development Network: Washington, DC, USA, 2006.

39. Pacheco, P.; Barry, D.; Cronkleton, P.; Larson, A.M. The Role of Formal Institutions in the Use of Forest Resources in Latin America; CIFOR: Bogor, Indonesia, 2008.

40. Del Gatto, F. Barreras a la Legalidad en el Sector Forestal en Honduras; La Tala Ilegal en Centroamerica: Tegucigalpa, Honduras, 2002; Available online: http://www.talailegalcentroamerica.org (accessed on 1 July 2010).

41. Ampié Bustos, E. La Produccion Forestal no Controlada en el Municipio de Puerto Cabezas, Región Atlántico Norte; Nicambiental: Managua, Nicaragua, 2002.

42. Contreras-Hermosilla, A.; Doornbosch, R.; Lodge, M. The Economics of Illegal Logging and Associate Trade; OECD General Secretariat: Paris, France, 2007.

43. Kaufmann, D.; Kraay, A.; Mastruzzi, M. Governance matters VIII; Policy Research Working Paper 4978; Development Research Group, The World Bank: Washington, DC, USA, 2009.

44. Perez Contreras, O. Adelantos y Progreso Alcanzado en Materias de Politicas de Compra de Maderas. In Estudio de Caso-Peru; International Tropical Timbet Organization: Yokohama, Japan, 2009; Available online: http://www.itto.int/direct/topics/topics_pdf.../topics_id=2304\&no=2 \&disp=inline (accessed on 14 November 2010).

45. Downie, A. Brazil's lofty climate goals depend on state, city and federal co-operation. In Special Issue: Take on Climate Change; Federations 2010, March/April, 16-18; Available online: http://www.forumfed.org/en/products/magazine/vol9_num1/V9N1_EN.pdf (accessed on 26 January 2011).

46. Contreras-Hermosilla, A.; Vargas Rios, M.T. Reformas a la Política Forestal de Bolivia. Impactos Sociales Ambientales y Económicos de los Primeros Cinco Años del Régimen Forestal Boliviano. Informe Especial CIFOR. Recursos Naturales y Ambiente 2007, 49-50, $44-57$.

47. Navarro, G.; Del Gatto, F.; Schroeder, M. Ecuador's outsourced national forest control system. In Legal Timber, Verification and Governance in the Forest Sector; Overseas Development Institute: London, UK, 2008.

48. Brazil National and State REDD; Environmental Defense Fund: Washington, DC, USA, 2009. 


\section{Appendix}

Appendix 1. Unintended negative effects of common forest policies.

\begin{tabular}{|c|c|c|c|}
\hline Policy & Economic Impact & Equity Impact & Environmental Impact \\
\hline $\begin{array}{l}\text { Supply of forest industrial } \\
\text { material at subsidized } \\
\text { prices to promote } \\
\text { industrial development }\end{array}$ & $\begin{array}{l}\text { Waste in harvesting } \\
\text { and industrial } \\
\text { processing. Reduction } \\
\text { of incentives to } \\
\text { sustainable forest } \\
\text { management. } \\
\text { Companies become } \\
\text { addicted to subsidies } \\
\text { and effectively lobby } \\
\text { to keep them. } \\
\text { Incentives to corrupt } \\
\text { deals. }\end{array}$ & $\begin{array}{l}\text { Large enterprise benefits } \\
\text { the most; small enterprises } \\
\text { benefit less or do not } \\
\text { benefit at all. Government } \\
\text { loses income. Private } \\
\text { forest landowners are } \\
\text { deprived of potentially } \\
\text { profitable forest } \\
\text { investments. }\end{array}$ & $\begin{array}{c}\text { Excessive levels of forest } \\
\text { cut, inadequate incentives } \\
\text { to maintain environmental } \\
\text { services of forests. }\end{array}$ \\
\hline $\begin{array}{l}\text { No recognition of } \\
\text { traditional forest land } \\
\text { ownership rights, to } \\
\text { concentrate presumably } \\
\text { superior decisions in the } \\
\text { hands of government }\end{array}$ & $\begin{array}{l}\text { Reduction of } \\
\text { incentives for local } \\
\text { people to invest in } \\
\text { forest management as } \\
\text { uncertainty of } \\
\text { resulting benefits } \\
\text { increases. }\end{array}$ & $\begin{array}{l}\text { Negative impact on the } \\
\text { poor and indigenous } \\
\text { groups that cannot use } \\
\text { their lands as a capital } \\
\text { asset. Use of forest lands } \\
\text { by external actors, such as } \\
\text { corporations in concession } \\
\text { areas impoverishes the } \\
\text { poor further and creates } \\
\text { conditions for social and } \\
\text { conflict and often violent } \\
\text { political upheaval }\end{array}$ & $\begin{array}{l}\text { Conflicts and uncertainty } \\
\text { contribute to } \\
\text { deforestation, propagation } \\
\text { of forest fires and general } \\
\text { degradation of the } \\
\text { forest environment. }\end{array}$ \\
\hline $\begin{array}{l}\text { No recognition of } \\
\text { traditional forest land } \\
\text { ownership rights, to } \\
\text { concentrate presumably } \\
\text { superior decisions in the } \\
\text { hands of government }\end{array}$ & $\begin{array}{c}\text { Reduction of } \\
\text { incentives for local } \\
\text { people to invest in } \\
\text { forest management as } \\
\text { uncertainty of } \\
\text { resulting benefits } \\
\text { increases. }\end{array}$ & $\begin{array}{l}\text { Negative impact on the } \\
\text { poor and indigenous } \\
\text { groups that cannot use } \\
\text { their lands as a capital } \\
\text { asset. Use of forest lands } \\
\text { by external actors, such as } \\
\text { corporations in concession } \\
\text { areas impoverishes the } \\
\text { poor further and creates } \\
\text { conditions for social and } \\
\text { conflict and often violent } \\
\text { political upheaval }\end{array}$ & $\begin{array}{l}\text { Conflicts and uncertainty } \\
\text { contribute to } \\
\text { deforestation, propagation } \\
\text { of forest fires and general } \\
\text { degradation of the } \\
\text { forest environment. }\end{array}$ \\
\hline
\end{tabular}


Appendix 1. Cont.

\begin{tabular}{|c|c|c|c|}
\hline Policy & Economic Impact & Equity Impact & Environmental Impact \\
\hline $\begin{array}{l}\text { Logging bans, to protect } \\
\text { the integrity of natural } \\
\text { forests }\end{array}$ & $\begin{array}{l}\text { Economic uses of } \\
\text { forest are closed. } \\
\text { Industry may have to } \\
\text { depend on higher } \\
\text { priced imports. The } \\
\text { commercial value of } \\
\text { existing forests may } \\
\text { decrease substantially, } \\
\text { thus reducing } \\
\text { profitability of } \\
\text { sustainable forest } \\
\text { management }\end{array}$ & $\begin{array}{l}\text { Loggers, including some low } \\
\text { income logging communities, } \\
\text { may go out of business. } \\
\text { Industrialists may see their } \\
\text { profitability reduce if } \\
\text { imported logs are pricier than } \\
\text { domestic supplies. Possible } \\
\text { contraction of logging and } \\
\text { industrial activity may reduce } \\
\text { rural and } \\
\text { industrial employment. }\end{array}$ & $\begin{array}{l}\text { Commercial value of } \\
\text { forest resources may be } \\
\text { reduced enough to } \\
\text { encourage conversion to } \\
\text { other more profitable } \\
\text { uses of land, particularly } \\
\text { if land is scarce. These } \\
\text { other uses may be less } \\
\text { environmentally } \\
\text { desirable than forest uses } \\
\text { of land. }\end{array}$ \\
\hline $\begin{array}{l}\text { All forest resources are } \\
\text { owned by the state, to } \\
\text { be managed by } \\
\text { government in closer } \\
\text { consonance with } \\
\text { societal objectives }\end{array}$ & $\begin{array}{c}\text { Disincentive to } \\
\text { investments in forest } \\
\text { management and } \\
\text { afforestation, } \\
\text { particularly on private } \\
\text { lands. }\end{array}$ & $\begin{array}{l}\text { Policy negatively affects land } \\
\text { owners that otherwise may } \\
\text { have engaged in rehabilitating } \\
\text { forest lands. Loggers and } \\
\text { industrialists have a greater } \\
\text { opportunity and incentive to } \\
\text { engage in corrupt acts. }\end{array}$ & $\begin{array}{l}\text { Policy may promote } \\
\text { deforestation to avoid } \\
\text { government control of } \\
\text { forest resources. }\end{array}$ \\
\hline $\begin{array}{l}\text { Land ownership is } \\
\text { contingent on } \\
\text { demonstration of } \\
\text { occupation }\end{array}$ & $\begin{array}{c}\text { Incentive to } \\
\text { deforestation to prove } \\
\text { land occupation. } \\
\text { Valuable economic } \\
\text { forest resources are } \\
\text { lost. }\end{array}$ & $\begin{array}{c}\text { This option is usually not } \\
\text { open to large corporations. } \\
\text { Small farmers may benefit by } \\
\text { obtaining land ownership but } \\
\text { by sacrificing potential forest } \\
\text { benefits that could have been } \\
\text { obtained in absence } \\
\text { of deforestation. }\end{array}$ & $\begin{array}{l}\text { Deforestation is an } \\
\text { effective way to prove } \\
\text { occupation. Incentive to } \\
\text { destructive } \\
\text { environmental practices. }\end{array}$ \\
\hline Plantation subsidies & $\begin{array}{l}\text { Cost to the national } \\
\text { treasury. Opportunities } \\
\text { for corruption and } \\
\text { misallocation of } \\
\text { economic resources } \\
\text { increase due to price } \\
\text { distortions. Economic } \\
\text { natural forest values } \\
\text { may be lost particularly } \\
\text { if plantations replace } \\
\text { natural forests. }\end{array}$ & $\begin{array}{l}\text { Large plantations may lead to } \\
\text { displacement of local people. } \\
\text { Traditional agrosilvicultural } \\
\text { methods of forest resource } \\
\text { management may be at a } \\
\text { disadvantage and displaced by } \\
\text { monocultures. Subsidies may } \\
\text { inflate land prices and thus } \\
\text { redistribute wealth to existing } \\
\text { landowners. Small, } \\
\text { undercapitalized landowners } \\
\text { may not be able to access } \\
\text { subsidies. Subsidies tend to } \\
\text { disproportionately favor large } \\
\text { corporations. }\end{array}$ & $\begin{array}{c}\text { Deforestation of natural } \\
\text { forest may occur to clear } \\
\text { land to establish } \\
\text { plantations. } \\
\text { Monocultures may } \\
\text { expand at the expense of } \\
\text { mixed natural forests. } \\
\text { Subsidies often lead to } \\
\text { extremely poor quality } \\
\text { of plantations. }\end{array}$ \\
\hline
\end{tabular}


Appendix 1. Cont.

\begin{tabular}{|c|c|c|c|}
\hline Policy & Economic Impact & Equity Impact & Environmental Impact \\
\hline Timber transit rules & $\begin{array}{l}\text { High transaction costs. } \\
\text { Policy opens } \\
\text { opportunities for } \\
\text { corruption and } \\
\text { misallocation of } \\
\text { resources. Depending on } \\
\text { the effectiveness of } \\
\text { government action, transit } \\
\text { restrictions may reduce } \\
\text { commercial value of } \\
\text { some timber species and } \\
\text { contribute to forests being } \\
\text { replaced by alternative } \\
\text { uses of land. }\end{array}$ & $\begin{array}{l}\text { Small producers may find } \\
\text { themselves at a commercial } \\
\text { disadvantage if they are } \\
\text { unable to pay bribes. Larger } \\
\text { corporations may control } \\
\text { controllers. }\end{array}$ & $\begin{array}{l}\text { In practice these rules have } \\
\text { had negligible impact on } \\
\text { the conservation of } \\
\text { forest resources. }\end{array}$ \\
\hline
\end{tabular}

(C) 2011 by the authors; licensee MDPI, Basel, Switzerland. This article is an open access article distributed under the terms and conditions of the Creative Commons Attribution license (http://creativecommons.org/licenses/by/3.0/). 